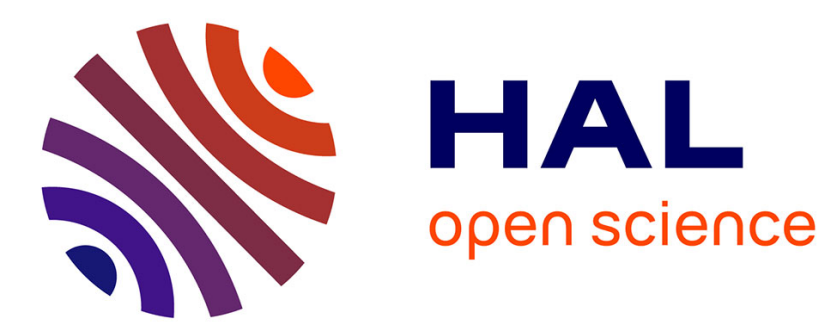

\title{
Lean and fat development in piglets
}

Florence Gondret, Louis Lefaucheur, Marie-Hélène Perruchot, Chantal

Farmer, Laurence Liaubet, Isabelle Louveau

\section{To cite this version:}

Florence Gondret, Louis Lefaucheur, Marie-Hélène Perruchot, Chantal Farmer, Laurence Liaubet, et al.. Lean and fat development in piglets. The suckling and weaned piglet, Wageningen Academic Publishers, pp.41-69, 2020, 978-90-8686-343-3. 10.3920/978-90-8686-894-0_2 . hal-02955307

\section{HAL Id: hal-02955307 https://hal.inrae.fr/hal-02955307}

Submitted on 1 Oct 2020

HAL is a multi-disciplinary open access archive for the deposit and dissemination of scientific research documents, whether they are published or not. The documents may come from teaching and research institutions in France or abroad, or from public or private research centers.
L'archive ouverte pluridisciplinaire HAL, est destinée au dépôt et à la diffusion de documents scientifiques de niveau recherche, publiés ou non, émanant des établissements d'enseignement et de recherche français ou étrangers, des laboratoires publics ou privés. 


\title{
2. Lean and fat development in piglets
}

\author{
F. Gondret ${ }^{1^{*}}$, L. Lefaucheur ${ }^{1}$, M.H. Perruchot ${ }^{1}$, C. Farmer ${ }^{2}$, L. Liaubet ${ }^{3}$ and I. Louveau ${ }^{1}$ \\ ${ }^{1}$ PEGASE, INRAE, Institut Agro, 35590 Saint-Gilles, France; ${ }^{2}$ Agriculture and Agri-Food \\ Canada, Sherbrooke R \& D Centre, Sherbrooke, QC, Canada; ${ }^{3}$ GenPhySE, Université de \\ Toulouse, INRAE,ENVT, Castanet Tolosan, France; florence.gondret@inrae.fr
}

\begin{abstract}
Piglets are immature at birth, which renders them highly sensitive to environmental conditions during the neonatal period. Lean and fat tissues are important components for survival and later growth capabilities. This chapter focuses on the development of skeletal muscle and adipose tissue during intra-uterine life, suckling and post-weaning. Available data show that the profile of myosin heavy chain isoforms and the glycogen content are good descriptors of skeletal muscle maturity around birth. Expression levels of key genes such as DLK1 and IGF2, regulating the transition from proliferation to differentiation of constitutive cell precursors, could also be assessed as indicators of the relative level of maturity in adipose tissue at this period. The provision of nutrients to foetuses affects the development of muscle and adipose tissues during gestation and alters their functionalities after birth. Spontaneous intra-uterine growth restriction markedly delays the genetically programmed development of lean and fat tissues and especially impairs the formation of myofibres, thereby reducing the adaptive abilities of small neonates to the extra-uterine environment. Maternal energy or protein overfeeding have no beneficial effects on muscle development in foetal pigs, but nutritional avenues using supplementary arginine or vitamin D in sow diets at specific periods of gestation may be favourable for foetal myogenesis. The best strategies to increase body fat content before birth and enhance lipolytic and oxidation capacities of piglets soon after birth remain to be developed. During the suckling period, myofibre composition and size undergo marked changes. Adipose tissue growth is also accelerated and this is exacerbated in small littermates with detrimental effects on their physiology later in life. Supplementing the diet of suckling or post-weaned piglets with branched-chain amino acids could improve muscle maturation and affect adipose tissue metabolism. With the multiplicity of factors acting on the development of muscle and fat tissues in piglets, identifying optimal feeding strategies remains difficult.
\end{abstract}

Keywords: adipogenesis, intra-uterine growth retardation, myogenesis, nutrition, weaning

\subsection{Introduction}

Muscle and adipose tissue are important body components because of their specific roles in neonatal vitality and growth efficiency in postnatal life. Skeletal muscles are fundamental components ensuring force, posture, movement and locomotion, notably 
enabling piglets to reach the teats. They are also involved in shivering thermogenesis during the neonatal period, which is of utmost importance for the regulation of body temperature and adaptation to the extra-uterine environment (Herpin et al., 2002). Muscles contain significant amounts of glycogen, an essential biochemical component that provides energy to piglets before they first suckle, as reviewed in Chapter 1 (Farmer and Edwards, 2020). Postnatal growth rate is also positively related to the total number of myofibres in skeletal muscles. There are indications that body fat depots may also be important for piglet survival and postnatal adaptation. More specifically, a positive relationship between the amount of body fat at birth and the birth-to-weaning survival was reported (Leenhouwers et al., 2002). Subcutaneous white adipose tissue (also called backfat) forms an insulating layer protecting newborn piglets against cold, making them somewhat less vulnerable to temperature fluctuations. This is especially important because piglets are devoid of brown adipose tissue which produces heat via the activation of uncoupling protein 1 (UCP1) in other mammals. Recently, a new type of adipocytes was discovered in white adipose tissue of mice and humans exposed to cold and hormonal stimuli: the beige/brite adipocytes (Sanchez-Gurmaches and Guertin, 2014). Even though the presence of beige adipocytes is still a controversy in the pig, there are some indications that cold-tolerant pigs can maintain their body temperature through the 'browning' of their white adipose tissue with an overexpression of UCP3 in the absence of UCP1 (Lin et al., 2017). Furthermore, white adipose tissue is recognized as a secretory or true endocrine organ regulating body homeostasis. Taking all this into consideration, it is essential to decipher the mechanisms leading to skeletal muscle and adipose tissue development during the prenatal, suckling, and post-weaning periods in order to better understand the factors affecting these tissues and develop strategies to enhance neonatal survival and postnatal growth in piglets.

\subsection{Foetal development determining the functionalities of muscle and fat tissues in neonates}

\subsubsection{Basic principles governing muscle and fat development}

The development of skeletal muscle and white adipose tissue depends on complex, continuous and interconnected biological processes that result from the commitment of embryonic stem cells to particular differentiation pathways (muscle, adipocyte, etc.). During the post-embryonic growth phases, there is an increase in the number (hyperplasia) and volume (hypertrophy) of the constituent cells, enabling the development and growth of muscle and fat tissues.

Multinucleated myofibres are the functional contractile units of skeletal muscles, hence, understanding the development and changes in the number and metabolism of myofibres during foetal life is of particular importance to unravel the mechanisms involved in muscle maturity around birth. The biphasic nature of myofibre ontogenesis during the foetal period is well illustrated in the pig. A primary generation of precursor cells (socalled myotubes) forms from 35 to 55 days of gestation, followed by a second generation between 55 and 90 days of gestation, which uses the primary myotubes as a scaffold 
(Lefaucheur $e t$ al., 1995). The number of secondary fibres around each primary myotube is approximately 20 to 25, depending on the muscle (Wigmore and Stickland, 1983). The total number of muscle fibres is considered to be almost fixed by 90 days of gestation. Throughout gestation, primary myotubes generally express the myosin heavy chain (MyHC) isoform I, and are destined to become slow-twitch type I fibres. In particular cases (e.g. the superficial white portion of the pig semitendinosus muscle), primary myotubes rather express adult fast $\mathrm{MyHC}$ isoforms during gestation and mature to fasttwitch type II fibres (Lefaucheur et al., 1995). Some secondary myofibres expressing MyHC I also start to express the $\alpha$-cardiac $\mathrm{MyHC}$ in late gestation (Lefaucheur et al., 1995). Altogether, the embryonic and foetal MyHC isoforms are predominant up to 90 days of gestation in skeletal muscles (Figure 2.1), whereas adult fast isoforms IIa and IIx increase in late gestation and IIb isoform appears only after birth.

Available data show that the profile of $\mathrm{MyHC}$ isoforms and the glycogen content, which increases dramatically in late gestation (going from 4 to $10 \%$ between 90 days of gestation and birth), are good descriptors of skeletal muscle maturity around birth (Voillet et al., 2018). Metabolically, all myofibres are oxidative at birth (Lefaucheur and Vigneron, 1986). In contrast to the total number of myofibres which markedly increases during gestation, their cross-sectional area remains rather constant during the foetal period (Lefaucheur, 2010).

Adipose tissue development occurs later than muscle development. White adipose tissue appears as a number of individual depots in the body, some under the skin (subcutaneous fat depots), some in the abdominal cavity (surrounding viscera such as mesenteric and perirenal fat depots, around the epididymis, etc.), and some within the musculature (interand intra-muscular depots). These depots have specific developments and vary in sizes. The first clusters of adipocytes appear subcutaneously at mid-gestation between 50 and 75 days (Hausman and Kauffman, 1986); then, the perirenal adipose tissue develops from approximately 70 days of gestation onward (Hausman and Thomas, 1986). Although fat gain in the body accelerates as of 69 days post-conception, pig neonates are characterized by a small amount of total body fat at birth (1-2\% of live weight). In all adipose tissues, adipocytes are recruited from populations of multipotent stem cells/progenitors. Besides pre-adipocytes defined as immature cells already engaged in the adipogenic lineage, there

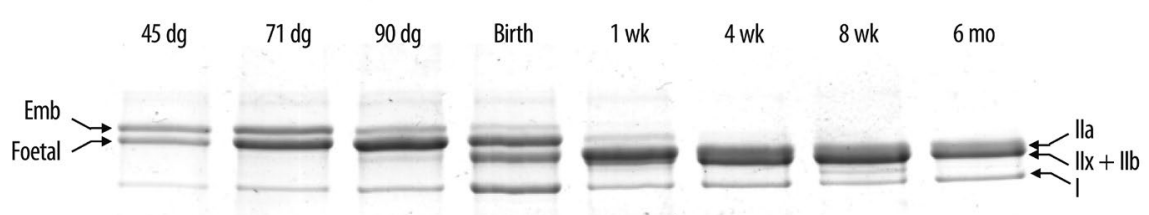

Figure 2.1. Composition of myosin heavy chain $(\mathrm{MyHC})$ isoforms of pig longissimus muscle from 45 days of gestation ( $\mathrm{dg}$ ) to a few weeks ( $w \mathrm{k}$ ) and months (mo) postnatally. The different isotypes were separated by electrophoresis (SDS-PAGE) and gel was stained with Coomassie blue G-250 solution. Bands were identified as embryonic (Emb), foetal and types I, Ila and (IIx + IIb) MyHC. 
are resident adult mesenchymal stem cells, also known as adipose tissue-derived stromal cells. As described in other species, the characterization of porcine adipose tissue-derived stromal cells is based on the expression of several clusters of differentiation markers (Monaco et al., 2012, Perruchot et al., 2013). The origin of adipose tissue-derived stromal cells and the detailed events leading to the early commitment of embryonic stem cells to the adipocyte lineage are only partially known in mammals (Louveau et al., 2016 for a review). Contrarily, the process whereby pre-engaged progenitors further develop into functioning adipocytes (adipogenesis) is well characterized and includes a large variety of orchestrated molecular and cellular changes (Gondret et al., 2013, 2018; Hausman et al., 2006; Ramsay and Caperna, 2009). A recent proteomic analysis of subcutaneous fat tissue in pig foetuses revealed that the mRNA abundance of many proteins involved in energy metabolism increases from 90 to 110 days of gestation (Gondret et al., 2018), suggesting an increased capacity for carbohydrate metabolism and oxidation in white adipose tissue of pig foetuses just before birth. Conversely, proteins participating in organization of the cytoskeleton were less abundant at 110 days of gestation than at 90 days of gestation, which may account for the programmed morphological changes of adipose cells that occur during the last month of gestation. The various steps of adipocyte differentiation are controlled by hormones and growth factors (Louveau and Gondret, 2004).

\subsubsection{Deviation from normal tissue development in piglets with intrauterine growth restriction}

Prenatal muscle growth and adipose tissue development are largely affected by foetal nutrition. The high prolificacy of modern sows causes an intra-uterine competition for nutrients among littermates, leading to intra-uterine growth restriction (IUGR) in a subset of them (about 15 to $20 \%$ of newborns). Lower circulating concentrations of glucose, arginine and glutamine are notably observed in the umbilical vein of IUGR foetuses compared with that of their normal littermates at 90 and 110 days of gestation (Lin et al., 2012), suggesting a reduced availability of nutrients. It is important to note that IUGR foetuses prioritize the growth of vital organs, such as the brain, at the expense of other organs, such as the liver, kidney, skeletal muscles and fat (Morise et al., 2008). The adaptive response to the intrauterine environment may depend on sex and genotype (Cogollos et al., 2017).

Thus, many cellular and molecular changes are observed in skeletal muscle and adipose tissue of IUGR piglets when compared with their normal-sized littermates. Of note, IUGR piglets have less total number of myofibres during gestation than do their normalsized and heavy littermates (Gondret et al., 2005; Rehfeldt and Kuhn, 2006). Available data suggest that the number of secondary fibres are specifically reduced in IUGR foetuses, thus leading to a reduction in the ratio of secondary to primary myofibres (Wigmore and Stickland, 1983). Foetal myogenesis in IUGR piglets is impaired due to many changes in the mRNA abundance of muscle proteins that are involved in cellular structure, macronutrient metabolism, protein synthesis and degradation, immune response, extracellular matrix and antioxidant function (Wang et al., 2008). The longissimus muscle of small foetuses especially exhibits higher expression levels of DLK1 and NCAM1/CD56 (Perruchot et al., 2015), two genes known to be downregulated 
during myogenesis in normal littermates. Expression levels of the embryonic MyHC, both at the mRNA and protein levels, are also higher in small foetuses, whereas the ratios of perinatal to embryonic and of adult fast to developmental $\mathrm{MyHC}$ isoforms are lower in IUGR foetuses when compared with their medium-weight littermates (Perruchot et al., 2015). Moreover, GLUT4, the muscle/fat specific glucose transporter, has a greater mRNA abundance in the muscle of small vs normal two-day-old piglets (Chriett et al., 2016), suggesting an early adaptation to maintain normoglycemia in the IUGR animals soon after birth (Gondret et al., 2013). Finally, IUGR muscles exhibit a reduced protein concentration and a lower creatine kinase/protein ratio, which also indicate a lower muscle maturity when compared with their normal-weight littermates (Rehfeldt and Kuhn, 2006). Changes in genome-wide methylation in skeletal muscles of IUGR piglets have also been characterized (Tao et al., 2019).

As reviewed in Chapter 1 (Farmer and Edwards, 2020), piglets with a low birth weight not only have reduced muscle development but also have a lower body fat content at birth when compared with their normal-weight littermates. Indeed, the transcriptional program of adipose tissue development is altered during gestation in IUGR piglets (Gondret et al., 2011, 2013). More specifically, the adipose tissue of IUGR piglets exhibits a sustained expression of $D L K 1$ gene during late gestation, thereby inhibiting preadipocyte proliferation and adipocyte differentiation (Traustadottir et al., 2013). During this period, the time-dependent increase in expression levels of many genes promoting adipocyte differentiation and lipogenesis are attenuated in IUGR foetuses. With regard to growth factors, spontaneous IUGR affects the IGF system leading to lower mRNA levels of IGF1 in white adipose tissue of piglets at 112 days of gestation and greater mRNA levels of IGF2 in 2-day-old piglets when compared with piglets harbouring a normal growth (Gondret et al., 2013). Whereas expression of the IGF1 gene is increased during adipocyte differentiation, expression level of the IGF2 gene is decreased (Gardan et al., 2008). Therefore, sustained expression levels of IGF2 and DLK1 around birth may contribute to delay the differentiation process of adipose tissue in IUGR piglets. The differences between IUGR piglets and normal littermates in terms of development of adipose tissue are particularly exacerbated two days after birth (Gondret et al., 2013).

Jointly with other body systems, the insufficient development of skeletal muscle and adipose tissues during gestation in small piglets will penalize their neonatal survival, growth potential and body composition during later life when compared with normalweight littermates.

\subsubsection{Maternal strategies to trigger the development of muscle and adipose tissue in pig foetuses}

Different nutritional interventions with the aim of optimizing in utero environment, preventing IUGR or specifically improving the development of muscle have been tested over the years, with the ultimate goal of influencing embryonic and neonatal survival, physiological maturity of neonates, and birth weight. 


\section{Overfeeding in gestation}

Twenty-five years ago, Dwyer et al. (1994) observed that doubling the feed intake of pregnant sows from days 25 to 50 , days 50 to 80 or days 25 to 80 tended to increase the total number of myofibres formed in the offspring during these periods, with a positive effect on postnatal growth of piglets. However, more recent studies showed conflicting results with greater (Gatford et al., 2003), similar (Markham et al., 2009; Nissen et al., 2003) or smaller (Cerisuelo et al., 2009) total number of myofibres in the progeny with maternal overfeeding. Birth weight of piglets from sows receiving an increased feed supply during gestation is generally not affected, as reviewed in Chapter 1 (Farmer and Edwards, 2020), and there are inconsistent results on the myofibre types and postnatal growth rate of those piglets (Bee 2004; Cerisuelo et al., 2009; Gatford et al., 2003; McNamara et al., 2011; Nissen et al., 2003). Moreover, overfeeding subsequent to a period of early maternal diet deprivation does not modify the expression levels of stem cell markers, myogenic signals and $\mathrm{MyHC}$ isoforms in skeletal muscle of piglets just before birth, but upregulates IGF2 expression (Perruchot et al., 2015). Such findings demonstrate that this feeding strategy aiming to induce catch-up growth in later gestation cannot counteract the deleterious effect of IUGR and, in fact, it even tends to reduce piglet birth weight when compared to sows fed adequate diets throughout gestation (Farmer et al., 2014). The possible impacts of maternal feed oversupply on the amount and functionality of adipose tissue in pig foetuses have not been investigated yet. However, it appears that some physiological limits may have been reached in high-prolific modern sows, whereby maternal overfeeding during gestation has no beneficial or even has detrimental effects on tissue development and physiological maturity of piglets.

\section{Dietary protein content}

Feeding sows a high protein and low carbohydrate diet during the whole gestation does not affect total number of myofibres nor does it influence the expression of myogenic regulatory factors or the proportion of $\mathrm{MyHC}$ isoforms in skeletal muscles of pig foetuses (Rehfeldt et al., 2012a,b). However, an in-depth study of the muscle transcriptome revealed changes in the mRNA expressions of many genes related to cell cycle regulation, energy metabolism, growth factor signalling pathways, and nucleic acid metabolism on day 1 after birth (Oster et al., 2012). Especially, expression levels of genes related to the organisation of filaments in skeletal muscle were greater in the offspring of sows fed a high-protein diet, which may improve the adaptive response of various cells, such as satellite cells, fat cells, and fibroblasts. A lower body fat content of foetuses is also observed in the last third of gestation with a maternal high protein diet (Kalbe et al., 2017), with even greater differences being present at birth (Rehfeldt et al., 2012a). A lower number of adipocytes (Rehfeldt et al., 2012a) and subtle changes in the functionality of white adipose tissue, including changes in protein abundance involved in carbohydrate recognition, amino acid metabolism and protein turnover, are notably observed in the neonates of sows fed a high protein and low carbohydrate diet during gestation (Sarr et al., 2010). These effects on muscle and adipose tissue are likely due to an energy deficit in treated sows, so that nutrients are partitioned in favour of maternal anabolism rather than foetal growth (Metges et al., 2012), thereby resulting in lower piglet birth weights (Rehfeldt et al., 2011). 


\section{Supplementation with specific amino acids}

A number of experiments dealt with the supplementation of specific amino acids in gestation diets. Many used arginine (Arg) because of its role as a precursor in the synthesis of numerous molecules such as nitric oxide (a vasodilator and angiogenic factor) and polyamines (that regulate protein synthesis and angiogenesis). A systematic review of 13 consolidated publications was recently published on the effects of maternal dietary Arg supplementation on foetal development in swine (Palencia et al., 2018). Although inconsistent data sometimes arose due to variations in amount of supplementation, period of pregnancy in which it is fed, and litter size, this systematic review showed overall positive results for embryo survival and foetal development. Another study confirmed the benefits of Arg supplementation on piglet birthweight, but for the smallest female littermates only (Oksbjerg et al., 2019). At day 75 of gestation, foetuses from sows fed $26 \mathrm{~g}$ of supplementary L-arginine daily from days 14 to 28 of gestation had more primary myofibres in their semitendinosus muscle than piglets from control sows (Bérard and Bee, 2010), but the development of white adipose tissue was not affected (Gondret et al., 2011). The benefits of dietary supplementation with Arg during early gestation on total number of myofibres in piglets at birth were recently confirmed (Madsen et al., 2017). Moreover, fibre diameters in the semitendinosus muscle of piglets from sows that received Arg from days 25 to 53 of gestation were enlarged when compared with control piglets (Garbossa et al., 2015). Whereas these results are encouraging when Arg is included in the sow diet during the first half of gestation, studies have generally reported no differences in total number of myofibres nor in their mean cross-sectional area in the longissimus muscle of neonates when sows are fed extra Arg during the whole gestation (Shi et al., 2018).

Another solution to improve muscle development in foetuses may be the use of L-carnitine as a premix or as a top-dressing supplement. Indeed, this derivative from lysine (Lys) and methionine (Met) has broad functions in carbohydrate and lipid metabolisms and affects the IGF system, which is important for muscle and fat tissue development. As expected, free and total carnitine concentrations are greater in the skeletal muscle of 70-day-old foetuses from sows fed supplemental L-carnitine during gestation (Brown et al., 2008). When compared with controls, the embryonic myoblasts isolated at mid-gestation from foetuses of treated sows had lower expression levels of IGF2 and myogenin, the latter being a muscle-specific transcription factor in myogenesis. In accordance with these effects, supplemental L-carnitine in the sow diet from breeding until day 110 of gestation increases muscling in piglets at birth (Musser et al., 2007). However, the hypothesis that L-carnitine supplementation can increase postnatal growth of piglets is not supported by data in later life (Ramanau et al., 2006).

\section{Vitamins}

Although some studies show that neonatal muscle characteristics are unaffected by maternal vitamin D supplementation (Flohr et al., 2016), others show a greater total number of myofibres in the longissimus muscle of piglets from sows treated with vitamin D compared with control sows at 90 days of gestation (Hines et al., 2013) and at birth (Zhou et al., 2016). This positive effect of maternal vitamin D status may be due to the 
fact that myoblasts derived from foetal muscles of treated sows display an extended proliferative phase (Hines et al., 2013). The mRNA levels for IGF2, myogenin and MyHCIIx (fast-twitch isoform) increased, whereas those for IGF1, myostatin and MyHC I (slowtwitch isoform) and the proportion of slow-twitch fibres decreased in newborns from sows treated with vitamin D during gestation (Zhou et al., 2016). It therefore seems that a greater maternal vitamin $\mathrm{D}$ status during gestation may favour prenatal muscle development of the offspring.

In conclusion, nutritional strategies applied to pregnant sows are largely unsuccessful to improve the development of skeletal muscle and adipose tissue of pig foetuses, except when specific amino acids or vitamins are used. Therefore, it would be more effective to propose strategies combining nutrient supply in gestation with other types of modifications in the prenatal environment. Because exposure of sows to a stressful environment during gestation has mild negative effects on the maturity and muscle tissue characteristics of piglets at birth (Quesnel et al., 2019), limiting maternal stress may be beneficial for piglet survival. Another successful strategy is to target the hormonal status of sows during gestation. Daily injections of porcine somatotropin (pST) to sows between days 10 and 27 of gestation increased the number of primary and secondary myofibres in the semitendinosus muscle of piglets at birth, and this specifically in low weight piglets (Rehfeldt et al., 2004). Furthermore, supplementation of sow diets with $20 \mathrm{mg} / \mathrm{kg}$ of ractopamine $\mathrm{HCl}$ from 25 to 53 days of gestation increased the mean size of myofibres in the semitendinosus muscle of piglets and also increased their birth weight (Garbossa et al., 2015). However, from a practical point of view, even though these growth-promoting agents do have some positive effects on myogenesis, their use is highly questionable and depends on the legislation of individual countries.

\subsubsection{Genetic influences on piglet maturity at birth}

When comparing maternal porcine breeds for the outcome of their offspring, it is evident that genetics has a great impact on the physiology and maturity of piglet tissues around birth. Even though lighter at birth than European Large White piglets, newborns from the Meishan breed (a Chinese fat breed) have a higher glycogen content in skeletal muscle (Voillet et al., 2018). They also have greater total body fat and mobilizable body fat, which contrasts with the positive relationship usually reported between body fat mass and birth weight in European breeds. Recent studies provide additional insights suggesting a greater maturity of muscle and white adipose tissue in Meishan than in Large White piglets during the last month of gestation (Gondret et al., 2018, Marti-Marimon et al., 2018; Voillet et al., 2014, 2018). For instance, the expression level of the embryonic $\mathrm{MyHC}$ isotype was lower in the longissimus muscle of Meishan foetuses at 90 days of gestation, whereas a greater proportion of fast (IIa + IIx + IIb) MyHC was observed at 110 days of gestation. Besides gluconeogenesis and glycolysis, the oxidation-reduction process in mitochondria was also shown to be greater in muscles of Meishan compared with Large White foetuses on day 110 of gestation (Voillet et al., 2018). This emphasizes the key role of oxidative metabolism for the maturity of neonatal muscle tissue. In white adipose tissue, there are indications of a better metabolic functionality (i.e. response to nutrient levels and lipogenic capacity) in Meishan than in Large White foetuses at 110 
days of gestation (Gondret et al., 2018). Reciprocal embryo transfer experiments between Meishan and Yorkshire genotypes further revealed that the maternal genotype determines placental size up to 90 days of gestation, hence, available space in the uterus. Thereafter, breed-specific foetal mechanisms appear to determine placental size (Biensen et al., 1998, 1999; Wilson et al., 1998, 1999). The genetic determinism of piglet maturity at birth was also analysed within Large White piglets when sows were inseminated with semen frozen at a 21 year-interval (Canario et al., 2007). As reviewed in Chapter 1 (Farmer and Edwards, 2020), piglets from sows inseminated with semen from 1,998 boars had less carcass protein and energy content than piglets born from sows inseminated with semen of 1,977 boars. These piglets also had less hepatic glycogen and lower plasma concentrations of glucose and IGF-I, indicating again a negative effect of selection for leanness and litter size on the maturity of tissues in neonatal piglets.

In addition, whole-genome scans such as Quantitative Trait Locus (QTL) studies or Genome-Wide Association Studies (GWAS) revealed that particular genomic regions are involved in the regulation of body composition and muscle and adipose tissue traits of piglets. Most of this information was provided from a PigQTL database (Hu et al., 2019) containing 29,045 QTLs/associations with 59 and 200 genes associated to 54 and 86 traits related to "muscle" or "fat", respectively. A subset of these genes had an expression level dependent on the parental origin. These so-called imprinted genes have key roles in the control of placental development and growth and metabolism of the foetuses. Reciprocal crosses between Large White and Meishan breeds allowed to investigate the impact of half of a genome coming from either the maternal or the paternal side. In total, 472 genes were identified in muscle as having an expression preferentially regulated by one parental genome, and most of these genes (366) were regulated by the paternal genome (Voillet et al., 2014). Among them, IGF2 was identified and gene associations were also revealed between IGF2, DLK1/MEG3 and MYH3 (embryonic MyHC) (Marti-Marimon et al., 2018). Genetic engineering thus holds promise for improving the development of foetal tissues to favour metabolism and survival of piglets. For example, insertion of the mouse UCP1 gene via the CRISPR/Cas9 technology can generate UCP1-knockin pigs that exhibit ectopic UCP1 expression in their white adipose tissue. This is associated with a decreased fat mass due to increased lipolysis and enhanced mitochondrial function in adipocytes, and improved thermoregulation of piglets exposed to cold at 1 month of age (Zheng et al., 2017).

\subsection{Muscle and fat tissue growth in suckling piglets}

\subsubsection{Postnatal development of lean and fat tissues}

The relative growth of skeletal muscle during the first postnatal week is extremely high and is greater than later in life. The chemical composition of muscles undergoes dramatic changes during the early postnatal period. Thus, muscle protein content is approximately $9 \%$ at birth, $15 \%$ at 3 weeks, $18 \%$ at 2 months and stabilizes at approximately $20 \%$ thereafter (Durand et al., 1967). Postnatal muscle growth is positively correlated with the total number of myofibres and is associated with hypertrophy of the myofibres that are present 
at birth (Dwyer et al., 1993). Postnatal muscle development results from an accretion of nuclei derived from satellite cells that undergo proliferation, differentiation and fusion with adjacent growing myofibres, so that the proliferation of satellite cells is particularly intense during the first postnatal weeks. Satellite cells can contribute to the formation of tertiary myofibres during the first postnatal days in pigs, even though the importance of this phenomenon for muscle growth and total number of myofibres remains unclear (Bérard et al., 2011; Lefaucheur et al., 1995; Mascarello et al., 1992; Miersh et al., 2017). Additionally, there is a dramatic increase in the accretion of myofibrillar protein within myofibres during the first five postnatal days (Herpin et al., 2002). Changes in the profile of $\mathrm{MyHC}$ isoforms are also seen during that time with a decrease in the amounts of embryonic and foetal MyHC isoforms in favour of the adult fast-twitch types IIa, IIx and IIb isoforms (Figure 2.1). The concentration of muscle glycogen is very high at birth ( $10 \%$ of fresh muscle) and rapidly decreases to reach 1 to $2 \%$ at 5 days of age, which is close to values reported for adult pigs (Herpin et al., 2002). Until 3 weeks of age, a subpopulation of secondary myofibres (located in the direct vicinity of primary myotubes) matures to type I fibres, leading to the typical and unique clusters of slow-twitch type I fibres surrounded by concentric rings of IIA, IIX and IIB fast-twitch fibres observed in pig muscles (Lefaucheur et al., 1995). A transitory expression of the a-cardiac MyHC, having contractile properties intermediate between those of type I and type IIa MyHC, also occurs in some slow-twitch fibres during the first few postnatal weeks, with a peak expression at around 10 days (Lefaucheur et al., 1997). Besides changes in contractile characteristics, there are important changes in the energy metabolism of myofibres, with glycolytic metabolism dramatically increasing during the first 2 to 3 weeks after birth (Lefaucheur and Vigneron, 1986). Oxidative metabolism, which is predominant at birth, increases until 2 to 3 weeks of age, followed by a gradual decrease. Altogether, the first 2 to 3 postnatal weeks are a critical period for muscle contractile and metabolic maturation in piglets (Harrison et al., 1997) until stabilization occurs starting at approximately 8 weeks of age.

Soon after birth, pigs have a remarkable capacity to store large amounts of fat. Depending on the colostral fat content, carcass fat increases by 25 to $100 \%$ during the first days of postnatal life (Le Dividich et al., 1997). Therefore, the body fat content evolves from 1-2\% at birth to reach $13 \%$ at 21 days of age (Frondas-Chauty, 2012). Total lipid content also increases between 7 and 30 days of age in both subcutaneous and perirenal fat (Hauser et al., 1997). During that same period, muscle lipid content (so-called intramuscular fat content, IMF) almost doubles. Furthermore, marked changes occur in morphology, cell size and chemical composition of adipose tissue. At birth adipocytes are generally multilocular, but by day 3 many unilocular adipocytes (with one major central lipid droplet) are observed (Hauser et al., 1997; Mersmann et al., 1975). A marked increase in adipocyte size is then seen with average diameter increasing from 19-24 $\mu \mathrm{m}$ at 3 days of age to $36 \mu \mathrm{m}$ at 23 days of age (Mersmann et al., 1973, 1975). A similar increase is reported in perirenal fat (Hauser et al., 1997). Importantly, an accelerated catch-up fat growth is observed in IUGR piglets during the suckling period so that the relative weight of perirenal adipose tissue, being lower in IUGR than in normal piglets at 7 days, no longer differs between the two birth weight groups at 28 days of age (Morise et al., 2009). Hence, many differences present at birth between IUGR and normal-sized littermates 
in terms of expression levels for adipose tissue genes are no longer apparent during suckling (Ramsay et al., 2010; Williams et al., 2009). To conclude, the suckling period is most particular in that myofibres and adipose tissue undergo marked changes and could therefore be highly responsive to nutritional and/or environmental stimuli in pig rearing systems.

\subsubsection{Nutritional and environmental manipulations to trigger tissue development in suckling piglets}

Feeding procedures of the suckling piglets and their rationale regarding postnatal survival and growth are detailed in Chapter 3 (Baxter et al., 2020). The current chapter focuses on the effects of different nutritional or environmental interventions on muscle and adipose tissue development in suckling piglets.

\section{Feed supply and intermittent feeding}

The effect of a feed restriction in the first weeks after birth on muscle maturation has received much attention. Responses differed according to muscle types. Indeed, more changes are generally reported in the longissimus, a large fast-twitch glycolytic muscle involved in movement, whereas the rhomboideus muscle, a slow-twitch oxidative muscle involved in posture, is not affected by feed restriction and seems to be better preserved (Lefaucheur et al., 2003). Enhancing nutrient supply in neonatal piglets is a key factor to increase muscle protein deposition rate, especially during the first postnatal week (Wilson et al., 2009). A high nutrient intake (1.5-fold the adequate level) during the suckling period leads to an enhanced expression of genes related to protein deposition and is associated with an accelerated maturation of glycolytic myofibres. These effects could be particularly advantageous in IUGR piglets (Hu et al., 2018). Importantly, muscle growth and protein synthesis are also greater when suckling piglets (1 to 3 weeks old) are fed intermittent meals rather than continuously, and this effect of intermittent feeding is likely related to the pulsatile patterns of insulin and amino acids levels (El-Kadi et al., 2018).

\section{Specific amino acid supply}

Skeletal muscles of newborn piglets are highly sensitive to dietary supplementation with specific amino acids during the first postnatal week (review by Rudar et al., 2019). Supplementation with different functional amino acids and some of their metabolites can potentially improve muscle maturation during the early postnatal period in suckling piglets. The branched chain amino acids, such as leucine (Leu), have the particularity to not be degraded in the liver, and hence to primarily serve for ATP synthesis in skeletal muscle. Leucine strongly stimulates protein synthesis in muscle from neonatal piglets through the mTOR pathway, providing that other amino acids and energy are available (Manjarin et al., 2018). Moreover, Leu also enhances the proliferation and differentiation of porcine satellite cells in an mTOR-dependent manner, which likely explains the in vivo effects on muscle growth (Han et al., 2008). Of practical importance to improve health status in young piglets, Leu supplementation may also limit the negative effects of 
diseases on muscle protein anabolism. Thus, parenteral Leu supplementation in newborn piglets attenuates the reduction in muscle protein synthesis induced by experimental endotoxemia (Hernandez-Garcia et al., 2016). The Leu metabolites a-ketoisocaproate and $\beta$-hydroxy- $\beta$-methylbutyrate similarly stimulate muscle protein synthesis (Duan et al., 2016) and can be successfully used in neonatal piglets (Escobar et al., 2010; Kao et al., 2016; Wheatley et al., 2014).

Because sow milk is poor in arginine (Arg), the effects of Arg supplementation during the early postnatal period has been investigated. Thus, dietary supplementation of lactating sows with Arg may stimulate piglet growth during the first postnatal week, likely through an increased concentration of total amino acids in sow milk (Mateo et al., 2008). In mice, in vitro experiments on $\mathrm{C} 2 \mathrm{C} 12$ myoblasts and in vivo studies report that Arg up-regulates the expression of slow-twitch type I MyHC, suggesting that Arg may play an important role in the determination of muscle fibre type, particularly through the Sirt1/AMPK signalling pathway (Chen et al., 2018). In adipose tissue, Arg is known to stimulate lipolysis and the expression of key genes responsible for activation of fatty acid oxidation, notably by inducing changes in mitochondrial biogenesis. Due to its role on the expression and activity of AMPK, Arg supplementation may modulate lipid metabolism towards the loss of triacylglycerols (Tan et al., 2012). Furthermore, Arg regulates adipocyte-muscle crosstalk and energy partitioning via the secretion of cytokines and hormones. These latter effects were observed in growing-finishing pigs, but data in suckling piglets are lacking.

\section{High protein diets}

The development of the offspring in response to feeding sows a high protein diet during lactation has recently been investigated (Schutkowski et al., 2018). Despite alterations in the sow nutrient status, the small changes seen in milk composition had basically no effects on growth and tissue development of the piglets. A better strategy is to feed piglets with a formula enriched in proteins. A high protein intake during the suckling period increases daily weight gain and leads to higher protein content and lower lipid content in the carcasses of 28-day-old piglets that are either small or normal at birth and reared in a well-controlled environment (Morise et al., 2009; Sarr et al., 2011). This reduction in adiposity is associated with a decrease in both lipid content and size of adipocytes in subcutaneous and perirenal adipose tissues (Sarr et al., 2012). Moreover, adipocytes with small diameters are present in greater proportions in adipose tissues of piglets fed a high protein formula, and the activity of lipogenic enzymes is decreased. Investigation of the adipose tissue proteome revealed that very little changes occur in the adipose tissue depots of IUGR piglets fed a high-protein formula, and that these changes take place in the subcutaneous rather than the perirenal adipose tissue (Sarr et al., 2012). The proteins affected are involved in signal transduction, redox status, carbohydrate metabolism and amino acid metabolism. More specifically, the lower abundance of annexin- 2 in piglets fed a high protein diet may be associated with their smaller adipocyte diameter and may have additional effects on glucose uptake. Altogether, findings indicate that a high protein intake during suckling may reduce or delay the development of adipose tissue while increasing protein deposition. 


\section{Ambient temperature}

Ambient temperature is an environmental factor that strongly influences the energy status of piglets. A remarkable adaptation of skeletal muscle to cold exposure has been reported during the first 5 postnatal days (Lefaucheur et al., 2001). When compared with piglets housed at thermoneutrality $\left(34-30{ }^{\circ} \mathrm{C}\right)$, cold exposure $\left(15-24^{\circ} \mathrm{C}\right)$ increased the proportion of type I and a-cardiac $\mathrm{MyHC}$ positive fibres in the longissimus and rhomboideus muscles and accelerated the reduction in the expression of foetal MyHC. Increases in muscle oxidative metabolism and fatty acid $\beta$-oxidation potential were also observed, and the number of lipid droplets within myofibres increased markedly in a cold environment (Herpin et al., 2002). These changes suggest an acceleration of postnatal muscle maturation in suckling piglets that are exposed to cold, which could be triggered by hormonal changes (e.g. thyroidal function) and muscle contraction through shivering.

\subsection{Muscle and fat tissue growth in weaned piglets}

\subsubsection{Effects of weaning on tissue physiology}

Risk factor analyses show that weaning weight and weight at 6 weeks of age are among the main factors predicting piglet body weight at the end of the nursery period (Paredes et al., 2012). Immediately after weaning, pigs often experience a reduction in growth rate which is due to multiple stress factors associated with weaning (maternal separation, relocation to new housing, introduction into new social groups, and adaptation to a dry diet). The process of weaning notably influences piglet feeding behaviour, resulting in a reduced feed intake and even anorexia. Weaning increases the concentrations of growth hormone and decreases the circulating concentrations of IGF-I and IGF-II in piglets (Carroll et al., 1998; Matteri et al., 2000). Autophagic vacuoles also markedly accumulate in skeletal muscles shortly after weaning, suggesting that the process of autophagy may be upregulated by the limited nutrient supply during this period (Zhang et al., 2011). Importantly, early weaning at 14 days of age induces an inflammation in the longissimus muscle of piglets lasting at least 7 days after weaning. There are also increases in the expression of MyHC I and IIx, UCP3 and AMPK (a major sensor of cellular energy deficit) at day 1 post-weaning, an increase in the activity of AMPK at day 3, and in the expression of MyHC IIb at days 5 and 7 (Li et al., 2016). During the entire pre-weaning period, most of the fatty acids used by piglets are obtained from maternal milk. Weaning is associated with an immediate shift to a low-fat high-carbohydrate diet composition; therefore, there is enhancement of enzyme activities associated with de novo fatty acid synthesis from glucose and acetate in the white adipose tissue of weaned piglets (Mersmann et al., 1976). The older the animals are at weaning, the greater is the increase in lipogenic activity in the post-weaning period (Mersmann et al., 1976). Moreover, early-weaned piglets can use body fat as an energy source to cope with the dramatic reduction of their feed intake (Fenton et al., 1985). This explains why body fat generally increases during the suckling and post-weaning periods in piglets weaned at standard ages, whereas early-weaned piglets ( 2 weeks of age) lose approximately $25 \%$ of their body fat during the first week post-weaning (Fenton et al., 1985). 


\subsubsection{Nutritional and environmental manipulations to trigger tissue development in weaned piglets}

Nutritional requirements and diet specifications of the weaned piglets are detailed in Chapter 10 (Lawlor et al., 2020). The current chapter describes the effects of different nutritional or environmental interventions on the growth and functioning of muscle and adipose tissue of post-weaned piglets.

\section{Specific amino acid supply}

After weaning, muscle growth and adipose tissue metabolism are still highly sensitive to deficiencies in amino acids, especially Lys (Katsumata et al., 2008) and total sulphur amino acids (TSAA: Met and Cys) (Castellano et al., 2015; Conde-Aguilera et al., 2016). Feeding a diet deficient in TSAA for 10 days to 6-week-old weaned piglets decreases the relative weight of the longissimus muscle, whereas that of the rhomboideus muscle is maintained (Conde-Aguilera et al., 2016). Dietary TSAA deficiency also increases the relative importance of oxidative metabolism in both muscles, but the response differs between muscles. Namely, a decrease in glycolytic metabolism is observed in the longissimus muscle whereas a dramatic increase in the proportion of type I fibres is observed in the red slow-twitch rhomboideus muscle. To the contrary, this dietary strategy increases total body fat and lipid content of the subcutaneous adipose tissue. Expression levels of genes involved in glucose uptake, lipogenesis, lipolysis, and activities of NADPH enzymatic suppliers are generally higher in subcutaneous and perirenal adipose tissues of TSAA deficient piglets, suggesting increased lipogenic and lipolytic rates (Castellano et al., 2015).

Because a deficiency in amino acids has such huge effects on lean and fat tissue development in post-weaned piglets, dietary supplementation with specific amino acids can be used to limit some negative effects of weaning. Whereas effects of feeding specific amino acids on post-weaning growth rate were demonstrated, their influence on the characteristics of lean and fat tissues remains to be studied. For instance, Leu supplementation in piglets weaned at 21 days of age alters the proteome profile of muscle analysed at day 35 of age, reducing oxidative phosphorylation and fatty acid $\beta$-oxidation but activating glycolysis (Fan et al., 2017). A reduction of AMPK activity is observed in muscles of piglets fed a Leu-supplemented diet. Such an inhibition of AMPK activity with dietary supplementation of Leu is also observed in cultured myoblasts (Du et al., 2007). However, contradictory results are reported when looking at porcine satellite cells, with Leu increasing slow-twitch type I MyHC and increasing expression of genes related to mitochondrial function through the activation (rather than inhibition) of the AMPK pathway (Chen et al., 2019). These controversial data point out the necessity to clarify the specific effects of Leu supplementation on the contractile and metabolic maturation of skeletal muscles in post-weaned piglets before providing any dietary recommendation for this growth period. Of note, in vivo and in vitro experiments have indicated that white adipose tissue is capable of metabolizing substantial amounts of branched chain amino acids (Leu, isoleucine and valine), which function as direct-acting nutrient signals for protein synthesis in adipose tissue. Supplying branched-chain amino acids in low-protein 
diets decreases the expression level of lipogenic genes in dorsal subcutaneous adipose tissue, but increases their expression level in abdominal subcutaneous and perirenal adipose tissues. Therefore, dietary supplementation with branched chain amino acids may alter the body fat condition of post-weaned piglets by modulating the expression of lipid metabolic regulators in a depot-specific manner (Li et al., 2017).

\section{Ambient temperature}

After weaning, piglets exposed to cold show a dramatic increase in the proportion of type I fibres in the oxidative rhomboideus muscle and similar, but much smaller, effects in the longissimus muscle (Harrison et al., 1996; Herpin and Lefaucheur, 1992). However, the oxidative soleus muscle is not affected by cold exposure (Harrison et al., 1996). A study carried out on pigs between 4 weeks of age and slaughter at $92 \mathrm{~kg}$ also reported a strong increase in the percentage of type I fibres and oxidative metabolism in the oxidative semispinalis muscle of cold-exposed pigs, with no effects in the longissimus muscle (Lefaucheur et al., 1991). Altogether, data indicate that the response of skeletal muscles to cold exposure is not simply related to muscle type, but may instead be associated to the specific physiological function of muscles. Piglets that are exposed to cold postweaning also exhibit less body fat (Faure et al., 2013). Three weeks of cold exposure in 5 - to 8-week-old piglets specifically increases the responsiveness of the lipolytic pathway in white adipose tissue, which may be of importance to supply substrates for tissues that are using fatty acids as an energy source (Herpin et al., 1991).

\subsection{Permanent effects of early postnatal events on muscle and fat tissues of pigs}

\subsubsection{Early nutrition}

According to the Barker hypothesis or the concept of 'metabolic programming' early events, especially those occurring in the perinatal period, may permanently affect growth, body composition, and health in adult life (Barker, 1990). With the selection of hyperprolific sows in recent years, the long-lasting impacts of the inherent low birth weights were examined in several studies (Lanferdini et al., 2018). For instance, it is well documented that the reduced total number of myofibres of IUGR neonatal piglets permanently decreases their postnatal growth (Gondret et al., 2006; Rehfeldt and Kuhn, 2006; Zhang et al., 2018). The reduction of muscle growth in IUGR piglets results from lower muscle protein synthesis as early as in the first postnatal week (El-Kadi et al., 2018), whereas satellite cells are not intrinsically different from those of normal birth weight littermates (Chen et al., 2017). The efficiency of protein utilization is also reduced during the growing and finishing periods in pigs that were small at birth (Zhang et al., 2018). Furthermore, small piglets at birth exhibit enlarged myofibre cross-sectional area at commercial slaughter weight (Bee, 2004; Gondret et al., 2005, 2006; Rehfeldt and Kuhn, 2006) and a greater proportion of MyHC IIb (Zhang et al., 2018) when compared with littermates of normal or heavy birth weight. 
The impacts of a lower birth weight on fat deposition are not consistent in the published literature. In some studies, an increase in subcutaneous fat thickness around puberty was reported in pigs that were small at birth compared with normal or heavy littermates (Gondret et al., 2006; Madsen and Bee, 2015). This increase in backfat was linked with a greater activity of lipogenic enzymes, a greater lipid content, and enlarged adipocytes in the adipose tissue of low compared with high birth weight pigs. Others found no difference in adiposity of pigs at commercial slaughter weight between low and normal birth weight littermates (Beaulieu et al., 2010; Bérard et al., 2008; Gondret et al., 2005). This discrepancy likely results from differences in postnatal feeding regimen (nutrient composition, amount fed, etc.). Indeed, the lower birth weight of piglets born from sows fed a high protein-low energy diet during gestation has little effect on the phenotype of their adipose tissue at puberty (Rehfeldt et al., 2012b). Furthermore, feeding a high protein formula to piglets during the suckling period results in similar body composition at peripuberty, despite enlarged adipocytes (Sarr et al., 2011, 2012). It therefore appears that inadequate nutrition during gestation and the suckling period has more longlasting effects on muscle tissue than on adipose tissue, likely because nutrition during the growing-finishing period largely affects the deposition and metabolism of fat.

\subsubsection{Genetic effects}

The genetic background obviously affects the postnatal development of pigs, hence, the biology of muscle and fat tissue during different periods of growth and the characteristics of these tissues around puberty. Heritabilities of muscle characteristics are moderate to high $\left(h^{2}=0.20\right.$ to 0.59; Larzul et al., 1997), and the highest heritabilities were found for some muscle traits such as the percentage of type IIB myofibres $\left(\mathrm{h}^{2}=0.58\right.$; Larzul et al., 1997) and intramuscular fat content $\left(\mathrm{h}^{2}=0.52\right.$; Won et al., 2018). Postnatal development is considered as a high-level combination of complex traits. For instance, Pena et al. (2016) explained that fat content and composition are highly polygenic, so that very few genes explain more than $5 \%$ of the variance of these two traits. The pig diversity in muscular and adipose genes has been explored by comparing different lines and breeds. When female and male Large White, Duroc, Landrace and Piétrain breeds were compared, the phosphoinositide 3 -kinase (PI3K) pathway was particularly affected, with 80 genes exhibiting a differential abundance between breeds (SanCristobal et al., 2015). This pathway is at the crosstalk of several biological processes including the control of skeletal muscle development where it affects, via the extracellular matrix, receptor interactions, actin cytoskeleton, glycolysis and glycogenesis. Moreover, Wimmers et al. (2006) produced a quantitative trait loci (QTL) scan for microstructural properties of pig muscle, showing that these traits are governed by genetic variations at many loci distributed throughout the genome. Most of the QTL identified have pleiotropic effects, which means that the same genes may affect different traits. Genome-wide association studies might help to decipher the molecular basis of fat and muscle traits, but the main difficulties are the cost and the invasiveness of sample collection. Nevertheless, it is possible to combine genome scan with studies on gene expression levels, protein abundances or metabolomics, to identify the genetic loci governing (or partially governing) gene expression levels for lean and fat tissues. In samples collected at slaughter, 335 expression QTL (eQTL) affecting the expression of 272 gene transcripts in skeletal muscle were identified (Liaubet et 
al., 2011). The underlying biology can be further determined by enrichment analysis of the biological processes (Liaubet et al., 2011) and construction of co-expression gene networks (Villa-Vialaneix et al., 2013). Such techniques allow the identification of particular regions involved in the regulation of multiple genes. For instance, COQ4 coding for the Coenzyme Q4 has been identified in muscle. In other species, a COQ4 mutation induced in pluripotent stem cells was associated with metabolic dysfunction and damaged skeletal muscle (Romero-Moya et al., 2017). These techniques also allow the identification of particular genes with a high centrality within the co-expression networks, suggesting that these genes may have important roles, although indirect, on a variety of pathways (e.g. GPI coding for the glucose-6-phosphate isomerase known to be involved in glycolysis and gluconeogenesis). Another strategy is to consider differentially expressed genes or candidate genes underlying the QTL regions; then, an eQTL scan for this short list of genes is performed to identify cis and trans-eQTL. For instance, the genetic determinism of intramuscular fat characteristics has been studied. First, significant associations between a genomic region on Sus scrofa chromosome SSC14 (110-114 Mb) and fatty acid composition (stearic, oleic, saturated and unsaturated fatty acid contents) in both gluteus medius and longissimus dorsi muscles were observed in Duroc pigs, highlighting the existence of a common genetic determinism (GonzalezPrendes et al., 2019). Then, the eQTL identification was realized only for the 74 genes located within the QTL region, and this analysis highlighted cis-eQTL for two genes (LGALS8 and KCNIP2) co-localizing with the QTL for stearic acid content.

Finally, when polymorphisms explaining most of the variations in a specific trait are identified, selection strategies against undesirable effects can be proposed. Examples are however scarce in pigs. Apart the well-known Halothane mutation (n allele) causing abnormal calcium release and lactic acid metabolism and poor meat quality (pale soft exudative) two other mutations were described. Namely, a mutation in the PRKAG3 gene increasing muscle glycolytic potential ( $\mathrm{RN}^{-}$allele; Salas and Mingala, 2017) and a mutation in IGF2 affecting muscle growth (Van Laere et al., 2003). However, special attention must be given to how genetic selection can negatively impact other traits, such as robustness. Indeed, selection to improve storage and clearance in muscle glycogen (to improve meat quality traits at slaughter) may have degraded the ability to store and mobilize glycogen during the first days after birth, thereby negatively affecting neonatal survival as reviewed in Chapter 1 (Farmer and Edwards, 2020).

\subsection{Conclusions}

The basic principles of muscle and adipose tissue development are now well characterized in piglets through the use of serial samples at different stages during the prenatal and postnatal periods as well as the isolation of precursor cells in controlled culture conditions. New insights from high throughput (-omics) technologies have completed the knowledge obtained from histological, biochemical and molecular target analyses. They have identified key genes and proteins that could serve as biological markers of physiological maturity to compare piglets at or soon after birth. Tissue development, which is under genetic and hormonal control, is largely affected by nutrition. However, 
the nutritional solutions to improve development of tissues and favour the establishment of intrinsic characteristics that could be beneficial for survival of piglets and further growth have yet to be developed. From the data obtained, it is likely that an ideal feeding regimen for sows and piglets does not exist due to many interactive factors, such as birth weight, variability in litter weight, sex, etc. Combined strategies including specific dietary ingredients (such as specific amino acids or plants with antioxidant, anti-inflammatory or phytogenic properties) and environmental conditions (stress reduction, temperature control, health status, etc.) need to be tested for sows and their neonates.

\section{References}

Barker, D.J., 1990. The fetal and infant origins of adult disease. British Medical Journal 301: 1111. https://doi.org/10.1136/bmj.301.6761.1111.

Baxter, E.M., Schmitt, O. and Pedersen, L.J., 2020. Managing the litter from hyperprolific sows. In: Farmer, C. (ed.) The suckling and weaned piglet. Wageningen Academic Publishers, Wageningen, the Netherlands, pp. 71-106.

Beaulieu, A.D., Aalhus, J.L., Williams, N.H. and Patience, J.F., 2010. Impact of piglet birth weight, birth order, and litter size on subsequent growth performance, carcass quality, muscle composition, and eating quality of pork. Journal of Animal Science 88: 2767-2778. https://doi. org/10.2527/jas.2009-2222.

Bee, G., 2004, Effect of early gestation feeding, birth weight, and gender of progeny on muscle fiber characteristics of pigs at slaughter. Journal of Animal Science 82: 826-836. https://doi. org/10.2527/2004.823826x.

Bérard, J. and Bee, G., 2010. Effects of dietary L-arginine supplementation to gilts during early gestation on foetal survival, growth and myofiber formation. Animal 4: 1680-1687. https://doi. org/10.1017/S1751731110000881.

Bérard, J., Kalbe, C., Lösel, D., Tuchscherer, A. and Rehfeldt C., 2011. Potential sources of earlypostnatal increase in myofibre number in pig skeletal muscle. Histochemical and Cellular Biology 136: 217-225. https://doi.org/10.1007/s00418-011-0833-z.

Bérard, J., Kreuzer, M. and Bee, G. 2008. Effect of litter size and birth weight on growth, carcass and pork quality, and their relationship to post-mortem proteolysis. Journal of Animal Science 86: 2357-2368. https://doi.org/10.2527/jas.2008-0893.

Biensen, N.J., Wilson, M.E. and Ford, S.P., 1998. The impact of either a Meishan or Yorkshire uterus on Meishan or Yorkshire fetal and placental development to days 70, 90, and 110 of gestation. Journal of Animal Science 76: 2169-2176. https://doi.org/10.2527/1998.7682169x.

Biensen, N.J., Wilson, M.E. and Ford, S.P., 1999. The impacts of uterine environment and fetal genotype on conceptus size and placental vascularity during late gestation in pigs. Journal of Animal Science 77: 954-959. https://doi.org/10.2527/1999.774954x.

Brown, K.R., Goodband, R.D., Tokach, M.D., Dritz, S.S., Nelssen, J.L., Minton, J.E., Higgins, J.J., Lin, X., Odle, J., Woodworth, J.C. and Johnson, B.J., 2008. Effects of feeding L-carnitine to gilts through day 70 of gestation on litter traits and the expression of insulin-like growth factor system components and L-carnitine concentration in foetal tissues. Journal of Animal Physiology and Animal Nutrition 92: 660-667. https://doi.org/10.1111/j.1439-0396.2007.00762.x. 
Canario, L., Père, M.C., Tribout, T., Thomas, F., David, C., Gogué, J., Herpin, P., Bidanel, J.P. and Le Dividich, J., 2007. Estimation of genetic trends from 1977 to 1998 of body composition and physiological state of Large White pigs at birth. Animal 1: 1409-1413. https://doi.org/10.1017/ S1751731107000766.

Carroll, J.A., Veum, T.L. and Matteri, R.L., 1998. Endocrine responses to weaning and changes in post-weaning diet in the young pig. Domestic Animal Endocrinology 15: 183-194. https://doi. org/10.1016/S0739-7240(98)00006-X

Castellano, R., Perruchot, M.H., Conde-Aguilera, J.A., Van Milgen, J., Collin, A., Tesseraud, S., Mercier, Y. and Gondret, F., 2015. A methionine deficient diet enhances adipose tissue lipid metabolism and alters anti-oxidant pathways in young growing pigs. PLoS ONE 10: e0130514. https://doi.org/10.1371/journal.pone.0130514.

Cerisuelo, A., Baucells, M.D., Gasa, J., Coma, J., Carrión, D., Chapinal, N. and Sala, R., 2009. Increased sow nutrition during midgestation affects muscle fiber development and meat quality, with no consequences on growth performance. Journal of Animal Science. 87: 729739. https://doi.org/10.2527/jas.2007-0677.

Chen, X., Guo, Y., Jia, G., Liu, G., Zhao, H. and Huang, Z., 2018. Arginine promotes skeletal muscle fiber type transformation from fast-twitch to slow-twitch via Sirt1/AMPK pathway. Journal of Nutrition and Biochemistry 61: 155-162. https://doi.org/10.1016/j.jnutbio.2018.08.007.

Chen, X., Xiang, L., Jia, G., Liu, G., Zhao, H. and Huang, Z., 2019. Leucine regulates slow-twitch muscle fibers expression and mitochondrial function by Sirt1/AMPK signaling in porcine skeletal muscle satellite cells. Animal Science Journal 90: 255-263. https://doi.org/10.1111/ asj.13146.

Chen, Y., Zhu, H., McCauley, S.R., Zhao, L., Johnson, S.E., Rhoads, R.P. and El-Kadi, S.W., 2017. Diminished satellite cell fusion and S6K1 expression in myotubes derived from skeletal muscle of low birth weight neonatal pigs. Physiological Reports 5: e13075. https://doi.org/10.14814/ phy2.13075.

Chriett, S., Le Huërou-Luron, I., Vidal, H. and Pirola, L. 2016. Dysregulation of sirtuins and key metabolic genes in skeletal muscle of pigs with spontaneous intrauterine growth restriction is associated with alterations of circulating IGF-1. General and Comparative Endocrinology 232: 76-85. https://doi.org/10.1016/j.ygcen.2015.12.028.

Cogollos, L., Garcia-Contreras, C., Vazquez-Gomez, M., Astiz, S., Sanchez-Sanchez, R., GomezFidalgo, E., Ovilo, C., Isabel, B. and Gonzalez-Bulnes, A., 2017. Effects of fetal genotype and sex on developmental response to maternal malnutrition. Reproduction Fertility Development 29: 1155-1168. https://doi.org/10.1071/RD15385.

Conde-Aguilera, J.A., Lefaucheur, L., Tesseraud, S., Mercier, Y., Le Floc'h, N. and Van Milgen, J., 2016. Skeletal muscles respond differently when piglets are offered a diet $30 \%$ deficient in total sulfur amino acid for 10 days. European Journal of Nutrition 55: 117-126. https://doi. org/10.1007/s00394-015-1031-X.

Du, M., Shen, Q.W., Zhu, M.J. and Ford, S.P., 2007. Leucine stimulates mammalian target of rapamycin signaling in $\mathrm{C} 2 \mathrm{C} 12$ myoblasts in part through inhibition of adenosine monophosphate-activated protein kinase. Journal of Animal Science 85: 919-927. https://doi. org/10.2527/jas.2006-342.

Duan, Y., Li, F., Li, Y., Tang, Y., Kong, X., Feng, Z., Anthony, T.G., Watford, M., Hou, Y., Wu, G. and Yin, Y., 2016. The role of leucine and its metabolites in protein and energy metabolism. Amino Acids 48: 41-51. https://doi.org/10.1007/s00726-015-2067-1. 
Durand, G., Fauconneau, G. and Penot, E., 1967. Evolution of muscle nucleic acid and protein content in pigs during postnatal development. Comptes rendus hebdomadaires des séances de l’Académie des sciences Série D: Sciences naturelles. 264: 1640-1643.

Dwyer, C.M., Fletcher, J.M. and Stickland, N.C., 1993. Muscle cellularity and postnatal growth in the pig. Journal of Animal Science 71: 3339-3343. https://doi.org/10.2527/1993.71123339x

Dwyer, C.M., Stickland, N.C. and Fletcher, J.M., 1994. The influence of maternal nutrition on muscle fiber number development in the porcine fetus and on subsequent postnatal growth. Journal of Animal Science 72: 911-917. https://doi.org/10.2527/1994.724911x

El-Kadi, S.W., Boutry, C., Suryawan, A., Gazzaneo, M.C., Orellana, R.A., Srivastava, N., Nguyen, H.V., Kimball, S.R., Fiorotto, M.L. and Davis, T.A, 2018. Intermittent bolus feeding promotes greater lean growth than continuous feeding in a neonatal piglet model. American Journal of Clinical Nutrition 108: 830-841. https://doi.org/10.1093/ajcn/nqy133.

Escobar, J., Frank, J.W., Suryawan, A., Nguyen, H.V., Van Horn, C.G., Hutson, S.M. and Davis, T.A., 2010. Leucine and alpha-ketoisocaproic acid, but not norleucine, stimulate skeletal muscle protein synthesis in neonatal pigs. Journal of Nutrition 140: 1418-1424. https://doi. org/10.3945/jn.110.123042.

Fan, Q., Long, B., Yan, G., Wang, Z., Shi, M., Bao, X., Hu, J., Li, X., Chen, C., Zheng, Z. and Yan, X., 2017. Dietary leucine supplementation alters energy metabolism and induces slow-to-fast transitions in longissimus dorsi muscle of weanling piglets. British Journal of Nutrition 117: 1222-1234. https://doi.org/10.1017/S0007114517001209.

Faure, J., Lebret, B., Bonhomme, N., Ecolan, P., Kouba, M. and Lefaucheur, L., 2013. Metabolic adaptation of two pig muscles to cold rearing conditions. Journal of Animal Science 91: 18931906. https://doi.org/10.2527/jas.2012-5828.

Farmer, C. and Edwards, S., 2020. The neonatal pig: developmental influences on vitality. In: Farmer, C. (ed.) The suckling and weaned piglet. Wageningen Academic Publishers, Wageningen, the Netherlands, pp. 9-39.

Farmer, C., Palin, M.F. and Martel-Kennes, Y., 2014. Impact of diet deprivation and subsequent overallowance during gestation on mammary gland development and lactation performance. Journal of Animal Science 92: 141-51. https://doi.org/10.2527/jas.2013-6558.

Fenton, J.P., Roehrig, K.L., Mahan, D.C. and Corley, J.R., 1985. Effect of swine weaning age on body fat and lipogenic activity in liver and adipose tissue. Journal of Animal Science 60: 190199. https://doi.org/10.2527/jas1985.601190x

Flohr, J.R., Woodworth, J.C., Bergstrom, J.R., Tokach, M.D., Dritz, S.S., Goodband, R.D. and DeRouchey, J.M., 2016. Evaluating the impact of maternal vitamin D supplementation: I. Sow performance, serum vitamin metabolites, and neonatal muscle characteristics. Journal of Animal Science 94: 4629-4642. https://doi.org/10.2527/jas.2016-0409.

Frondas-Chauty, A., Louveau, I., Le Huërou-Luron, I., Rozé, J.C. and Darmaun, D., 2012. Airdisplacement plethysmography for determining body composition in neonates: validation using live piglets. Pediatric Research 72: 26-31. https://doi.org/10.1038/pr.2012.35.

Garbossa, C.A., Carvalho Júnior, F.M., Silveira, H., Faria, P.B., Schinckel, A.P., Abreu, M.L. and Cantarelli, V.S., 2015. Effects of ractopamine and arginine dietary supplementation for sows on growth performance and carcass quality of their progenies. Journal of Animal Science 93: 2872-2884. https://doi.org/10.2527/jas.2014-8824.

Gardan, D., Mourot, J. and Louveau, I., 2008. Decreased expression of the IGF-II gene during porcine adipose cell differentiation. Molecular and Cellular Endocrinology 292: 63-68. https:// doi.org/10.1016/j.mce.2008.06.015. 
Gatford, K.L., Ekert, J.E., Blackmore, K., De Blasio, M.J., Boyce, J.M., Owens, J.A., Campbell, R.G. and Owens, P.C., 2003. Variable maternal nutrition and growth hormone treatment in the second quarter of pregnancy in pigs alter semitendinosus muscle in adolescent progeny. British Journal of Nutrition 90: 283-293. https://doi.org/10.1079/bjn2003893.

Gondret, F., Guével B., Père, M.C., Quesnel, H., Billon, Y., Com, E., Canario, L., Louveau, I. and Liaubet, L., 2018. Proteomic analysis of adipose tissue during the last weeks of gestation in pure and crossbred Large White or Meishan fetuses gestated by sows of either breed. Journal of Animal Science and Biotechnology 9: 28. https://doi.org/10.1186/s40104-018-0244-2.

Gondret, F., Lefaucheur, L., Juin, H., Louveau, I. and Lebret, B., 2006. Low birth weight is associated with enlarged muscle fiber area and impaired meat tenderness of the longissimus muscle in pigs. Journal of Animal Science 84: 93-103. https://doi.org/10.2527/2006.84193x.

Gondret, F., Lefaucheur, L., Louveau, I., Lebret, B., Pichodo, X. and Le Cozler, Y., 2005. Influence of piglet birth weight on postnatal growth performance, tissue lipogenic capacity and muscle histological traits at market weight. Livestock Production Science 93: 137-146. https://doi. org/10.1016/j.livprodsci.2004.09.009.

Gondret, F., Père, M.C., Tacher, S., Daré, S., Tréfeu, C., Le Huërou-Luron, I. and Louveau, I., 2013. Spontaneous intra-uterine growth restriction modulates the endocrine status and the developmental expression of genes in porcine fetal and neonatal adipose tissue. General and Comparative Endocrinology 194: 208-216. https://doi.org/10.1016/j.ygcen.2013.09.018.

Gondret, F., Perruchot, M.H., Tacher, S., Bérard, J. and Bee, G., 2011. Differential gene expressions in subcutaneous adipose tissue pointed to a delayed adipocytic differentiation in small pig fetuses compared to their heavier siblings. Differentiation 81: 253-260. https://doi. org/10.1016/j.diff.2011.02.002.

Gonzalez-Prendes, R., Quintanilla, R., Marmol-Sanchez, E., Pena, R.N., Ballester, M., Cardoso, T.F., Manunza, A., Casellas, J., Canovas, A., Diaz, I., Noguera, J.L., Castello, A., Mercade, A. and Amills, M., 2019. Comparing the mRNA expression profile and the genetic determinism of intramuscular fat traits in the porcine gluteus medius and longissimus dorsi muscles. BMC Genomics 20: 170. https://doi.org/10.1186/s12864-019-5557-9.

Han, B., Tong, J., Zhu, M.J., Ma, C. and Du, M., 2008. Insulin-like growth factor-1 (IGF-1) and leucine activate pig myogenic satellite cells through mammalian target of rapamycin (mTOR) pathway. Molecular Reproduction Development 75: 810-817. https://doi.org/10.1002/ mrd.20832.

Hauser, N., Mourot, J., De Clercq, L., Genart, C. and Remacle, C., 1997. The cellularity of developing adipose tissues in Pietrain and Meishan pigs. Reproduction Nutrition and Development 37: 617-625. https://doi.org/10.1051/rnd:19970601.

Hausman, G.J. and Kauffman, R.G., 1986. The histology of developing porcine adipose tissue. Journal of Animal Science 63: 642-658. https://doi.org/10.2527/jas1986.632642x.

Hausman, G.J. and Thomas, G.B., 1986. Structural and histochemical aspects of perirenal adipose tissue in fetal pigs: relationships between stromal-vascular characteristics and fat cell concentration and enzyme activity. Journal of Morphology 190: 271-283. https://doi. org/10.1002/jmor.1051900304.

Hausman, G.J., Poulos, S.P., Richardson, R.L., Barb, C.R., Andacht, T., Kirk, H.C. and Mynatt, R.L., 2006. Secreted proteins and genes in fetal and neonatal pig adipose tissue and stromal-vascular cells. Journal of Animal Science 84: 1666-1681. https://doi.org/10.2527/jas.2005-539. 
Harrison, A.P., Latorre, R. and Dauncey, M.J., 1997. Postnatal development and differentiation of myofibres in functionally diverse porcine skeletal muscles. Reproduction and Fertility Development 9: 731-740. https://doi.org/10.1071/R97026.

Harrison, A.P., Rowlerson, A.M. and Dauncey, M.J., 1996. Selective regulation of myofiber differentiation by energy status during postnatal development. American Journal of Physiology. 270: R667-R674. https://doi.org/10.1152/ajpregu.1996.270.3.R667.

Hernandez-García, A.D., Columbus, D.A., Manjarín, R., Nguyen, H.V., Suryawan, A., Orellana, R.A. and Davis, T.A., 2016. Leucine supplementation stimulates protein synthesis and reduces degradation signal activation in muscle of newborn pigs during acute endotoxemia. American Journal of Physiology 311: E791-E801. https://doi.org/10.1152/ajpendo.00217.2016.

Herpin, P. and Lefaucheur, L., 1992. Adaptive changes in oxidative metabolism in skeletal muscle of cold-acclimated piglets. Journal of Thermal Biology 17: 277-285. Https://doi. org/10.1016/0306-4565(92)90067-P.

Herpin, P., Bertin, R., De Marco, F., Portet, R. and Le Dividich, J., 1991. Adipose tissue lipolytic activity and urinary catecholamine excretion in cold-acclimated piglets. Canadian Journal of Physiology and Pharmacology 69: 362-368. https://doi.org/10.1139/y91-055.

Herpin, P., Lossec, G., Schmidt, I., Cohen-Adad, F., Duchamp, C., Lefaucheur, L., Goglia, F. and Lanni, A., 2002. Effect of age and cold exposure on morphofunctional characteristics of skeletal muscle in neonatal pigs. Pflugers Archives 444: 610-618. https://doi.org/10.1007/ s00424-002-0867-0.

Hines, E.A., Coffey, J.D., Starkey, C.W., Chung, T.K. and Starkey, J.D., 2013. Improvement of maternal vitamin D status with 25-hydroxycholecalciferol positively impacts porcine fetal skeletal muscle development and myoblast activity. Journal of Animal Science 91: 4116-4122. https://doi.org/10.2527/jas.2013-6565. https://doi.org/10.2527/jas.2013-6565.

Hu, L., Han, F., Chen, L., Peng, X., Chen, D., Wu, C., Che, L. and Zhang, K., 2018, High nutrient intake during the early postnatal period accelerates skeletal muscle fiber growth and maturity in intrauterine growth-restricted pigs. Genes and Nutrition 13: 23. https://doi.org/10.1186/ s12263-018-0612-8.

Hu, Z.L., Park, C.A. and Reecy, J.M., 2019. Building a livestock genetic and genomic information knowledgebase through integrative developments of Animal QTLdb and CorrDB. Nucleic Acids Research 47: D701-D710. https://doi.org/10.1093/nar/gky1084.

Kalbe, C., Lösel, D., Block, J., Lefaucheur, L., Brüssow, K.P., Bellmann, O., Pfuhl, R., Puppe, B., Otten, W., Metges, C.C. and Rehfeldt, C., 2017. Moderate high or low maternal protein diets change gene expression but not the phenotype of skeletal muscle from porcine fetuses. Domestic Animal Endocrinology 58: 63-75. https://doi.org/10.1016/j.domaniend.2016.08.003.

Kao, M., Columbus, D.A., Suryawan, A., Steinhoff-Wagner, J., Hernandez-Garcia, A., Nguyen, H.V., Fiorotto, M.L. and Davis, T.A., 2016. Enteral $\beta$-hydroxy- $\beta$-methylbutyrate supplementation increases protein synthesis in skeletal muscle of neonatal pigs. American Journal of Physiology 310: E1072-E1084. https://doi.org/10.1152/ajpendo.00520.2015.

Katsumata, M., Matsumoto, M., Kobayashi, S.I. and Kaji, Y., 2008. Reduced dietary lysine enhances proportion of oxidative fibers in porcine skeletal muscle. Animal Science Journal 79: 347-353. https://doi.org/10.1111/j.1740-0929.2008.00536.x.

Lanferdini, E., Andretta, I., Fonseca, L.S., Moreira, R.H.R., Cantarelli, V.S., Ferreira, R.A., Saraiva, A. and Abreu, M.L.T., 2018. Piglet birth weight, subsequent performance, carcass traits and pork quality: A meta-analytical study. Livestock Science 214: 175-179. https://doi. org/10.1016/j.livsci.2018.05.019. 
Larzul, C., Lefaucheur, L., Ecolan, P., Gogué, J., Talmant, A., Sellier, P., Le Roy, P. and Monin, G., 1997. Phenotypic and genetic parameters for longissimus muscle fiber characteristics in relation to growth, carcass, and meat quality traits in large white pigs. Journal of Animal Science 75: 3126-3137. https://doi.org/10.2527/1997.75123126x.

Lawlor, P., Gardiner, G.E. and Goodband, R.D., 2020. Feeding the weaned piglets. In: Farmer, C. (ed.) The suckling and weaned piglet. Wageningen Academic Publishers, Wageningen, the Netherlands, pp. 251-275.

Le Dividich, J., Herpin, P., Paul, E. and Strullu, F., 1997. Effect of fat content of colostrum on voluntary colostrum intake and fat utilization in newborn pigs. Journal of Animal Science 75: 707-713. https://doi.org/10.2527/1997.753707x

Leenhouwers, J.I., Knol, E.F., De Groot, P.N., Vos, H. and Van der Lende, T., 2002. Fetal development in the pig in relation to genetic merit for piglet survival. Journal of Animal Science 80: 17591770. https://doi.org/10.2527/2002.8071759x.

Lefaucheur, L., 2010. A second look into fibre typing-relation to meat quality. Meat Science 84: 257-270. https://doi.org/10.1016/j.meatsci.2009.05.004.

Lefaucheur, L. and Vigneron, P., 1986. Post-natal changes in some histochemical and enzymatic characteristics of three pig muscles. Meat Science 16: 199-216. https://doi.org/10.1016/03091740(86)90026-4.

Lefaucheur, L., Ecolan, P., Barzic, Y.M., Marion, J. and Le Dividich, J., 2003. Early postnatal food intake alters myofiber maturation in pig skeletal muscle. Journal of Nutrition 133: 140-147. https://doi.org/10.1093/jn/133.1.140.

Lefaucheur, L., Ecolan, P., Lossec, G., Gabillard, J.C., Butler-Browne, G.S. and Herpin, P., 2001. Influence of early postnatal cold exposure on myofiber maturation in pig skeletal muscle. Journal of Muscle Research and Cell Motility 22: 439-452. https://doi.org/10.1023/A:1014591818870.

Lefaucheur, L., Edom, F., Ecolan, P. and Butler-Browne, G.S., 1995. Pattern of muscle fiber type formation in the pig. Developmental Dynamics 203: 27-41. https://doi.org/10.1002/ aja.1002030104.

Lefaucheur, L., Hoffman, R., Okamura, C., Gerrard, D., Léger, J.J., Rubinstein, N. and Kelly, A., 1997. Transitory expression of alpha cardiac myosin heavy chain in a subpopulation of secondary generation muscle fibers in the pig. Developmental Dynamics 210: 106-116. https:// doi.org/10.1002/(SICI)1097-0177(199710)210:2<106::AID-AJA4>3.0.CO;2-K.

Lefaucheur, L., Le Dividich, J., Mourot, J., Monin, G., Ecolan, P. and Krauss, D., 1991. Influence of environmental temperature on growth, muscle and adipose tissue metabolism, and meat quality in swine. Journal of Animal Science 69: 2844-2854. https://doi.org/10.2527/1991.6972844x.

Li, F., Li, Y., Tan, B., Wang, J., Duan, Y., Guo, Q., Liu, Y., Kong, X., Li, T., Tang, Y. and Yin, Y., 2016. Alteration of inflammatory cytokines, energy metabolic regulators, and muscle fiber type in the skeletal muscle of post-weaning piglets. Journal of Animal Science 94: 1064-1972. https:// doi.org/10.2527/jas.2015-9646.

Li, Y., Wei, H., Li, F., Duan, Y., Guo, Q. and Yin, Y., 2017. Effects of low-protein diets supplemented with branched-chain amino acid on lipid metabolism in white adipose tissue of piglets. Journal of Agriculture and Food Chemistry 65: 2839-2848. https://doi.org/10.1021/acs.jafc.7b00488.

Liaubet, L., Lobjois, V., Faraut, T., Tircazes, A., Benne, F., Iannuccelli, N., Pires, J., Glénisson, J., Robic, A., Le Roy, P., Sancristobal, M. and Cherel, P., 2011. Genetic variability of transcript abundance in pig peri-mortem skeletal muscle: eQTL localized genes involved in stress response, cell death, muscle disorders and metabolism. BMC Genomics 12: 548. https://doi. org/10.1186/1471-2164-12-548. 
Lin, G, Liu, C., Feng, C., Fan, Z., Dai, Z., Lai, C., Li, Z., Wu, G. and Wang, J., 2012. Metabolomic analysis reveals differences in umbilical vein plasma metabolites between normal and growthrestricted fetal pigs during late gestation. Journal of Nutrition 142: 990-998. https://doi. org/10.3945/jn.111.153411. https://doi.org/10.3945/jn.111.153411.

Lin, J., Cao, C., Tao, CI, Ye, R., Dong, M., Zheng, Q., Wang, C., Jiang, X., Qin, G., Yan, C., Li, K., Speakman, J.R., Wang, Y., Jin, W. and Zhao, J., 2017. Cold adaptation in pigs depends on UCP3 in beige adipocytes. Journal of Molecular and Cellular Biology 9: 364-375. https://doi. org/10.1093/jmcb/mjx018.

Louveau, I. and Gondret, F., 2004. Regulation of development and metabolism of adipose tissue by growth hormone and the insulin-like growth factor system. Domestic Animal Endocrinology 27: 241-255. https://doi.org/10.1016/j.domaniend.2004.06.004.

Louveau, I., Perruchot, M.H., Bonnet, M. and Gondret, F., 2016. Invited review: Pre- and postnatal adipose tissue development in farm animals: from stem cells to adipocyte physiology. Animal. 10: 1839-1847. https://doi.org/10.1017/S1751731116000872.

Madsen, J.G and Bee, G., 2015. Compensatory growth feeding strategy does not overcome negative effects on growth and carcass composition of low birth weight pigs. Animal 9: 427-436. https:// doi.org/10.1017/S1751731114002663.

Madsen, J.G., Pardo, C., Kreuzer, M. and Bee, G., 2017. Impact of dietary L-arginine supply during early gestation on myofiber development in newborn pigs exposed to intra-uterine crowding. Journal of Animal Science and Biotechnology 8: 58. https://doi.org/10.1186/s40104-0170188-y.

Manjarín, R., Columbus, D.A., Solis, J., Hernandez-García, A.D., Suryawan, A., Nguyen, H.V., McGuckin, M.M., Jimenez, R.T., Fiorotto, M.L. and Davis, T.A., 2018. Short- and long-term effects of leucine and branched-chain amino acid supplementation of a protein- and energyreduced diet on muscle protein metabolism in neonatal pigs. Amino Acids 50: 943-959. https:// doi.org/10.1007/s00726-018-2572-0.

Markham, T.C., Latorre, R.M., Lawlor, P.G., Ashton, C.J., McNamara, L.B., Natter, R., Rowlerson, A. and Stickland, N.C., 2009. Developmental programming of skeletal muscle phenotype/ metabolism. Animal 3: 1001-1012. https://doi.org/10.1017/S1751731109004637.

Marti-Marimon, M., Vialaneix, N., Voillet, V., Yerle-Bouissou, M., Lahbib-Mansais, Y. and Liaubet, L., 2018. A new approach of gene co-expression network inference reveals significant biological processes involved in porcine muscle development in late gestation. Scientific Reports 8: 10150. https://doi.org/10.1038/s41598-018-28173-8.

Mascarello, F., Stecchini, M.L., Rowlerson, A. and Ballocchi, E., 1992. Tertiary myotubes in postnatal growing pig muscle detected by their myosin isoform composition. Journal of Animal Science 70: 1806-1813. https://doi.org/10.2527/1992.7061806x.

Mateo, R.D., Wu, G., Moon, H.K., Carroll, J.A. and Kim, S.W., 2008. Effects of dietary arginine supplementation during gestation and lactation on the performance of lactating primiparous sows and nursing piglets. Journal of Animal Science 86: 827-835. https://doi.org/10.2527/ jas.2007-0371.

Matteri, R.L., Dyer, C.J., Touchette, K.J., Carroll, J.A. and Allee, G.L., 2000. Effects of weaning on somatotrophic gene expression and circulating levels of insulin-like growth factor-1 (IGF1) and IGF-2 in pigs. Domestic Animal Endocrinology 19: 247-259. https://doi.org/10.1016/ S0739-7240(00)00081-3. 
McNamara, L.B., Giblin, L., Markham, T., Stickland, N.C., Berry, D.P., O’Reilly, J.J., Lynch, P.B., Kerry, J.P. and Lawlor, P.G., 2011. Nutritional intervention during gestation alters growth, body composition and gene expression patterns in skeletal muscle of pig offspring. Animal 5: 1195-1206. https://doi.org/10.1017/S1751731111000176.

Mersmann, H.J., Allen, C.D., Steffen, D.G., Brown, L.G. and Danielson, D.M., 1976. Effect of age, weaning and diet on swine adipose tissue and liver lipogenesis. Journal of Animal Science 43: 140-150. https://doi.org/10.2527/jas1976.431140x.

Mersmann, H.J., Goodman, J.R. and Brown, L.J., 1975. Development of swine adipose tissue: morphology and chemical composition. Journal of Lipid Research 16: 269-279.

Mersmann, H.J., Underwood, M.C., Brown, L.J. and Houk, J.M., 1973. Adipose tissue composition and lipogenic capacity in developing swine. American Journal of Physiology 224: 1130-1135. https://doi.org/10.1152/ajplegacy.1973.224.5.1130.

Metges, C.C., Lang, I.S., Hennig, U., Brüssow, K.P., Kanitz, E., Tuchscherer, M., Schneider, F., Weitzel, J.M., Steinhoff-Ooster, A., Sauerwein, H., Bellmann, O., Nürnberg, G., Rehfeldt, C. and Otten, W., 2012. Intrauterine growth retarded progeny of pregnant sows fed high protein:low carbohydrate diet is related to metabolic energy deficit. PLoS ONE 7: e31390. https://doi.org/10.1371/journal.pone.0031390.

Miersch, C., Stange, K., Hering, S., Kolisek, M., Viergutz, T. and Rontgen, M., 2017. Molecular and functional heterogeneity of early postnatal porcine satellite cell populations is associated with bioenergetic profile. Scientific Reports 7: 45052-45065. https://doi.org/10.1038/srep45052.

Monaco, E., Bionaz, M., Rodriguez-Zas, S., Hurley, W.L. and Wheeler, M.B., 2012. Transcriptomics comparison between porcine adipose and bone marrow mesenchymal stem cells during in vitro osteogenic and adipogenic differentiation. PLoS ONE 7: e32481. https://doi.org/10.1371/ journal.pone.0032481.

Morise, A., Louveau, I. and Le Huërou-Luron, I., 2008. Growth and development of adipose tissue and gut and related endocrine status during early growth in the pig: impact of low birth weight. Animal 2: 73-83. https://doi.org/10.1017/S175173110700095X.

Morise, A., Sève, B., Macé, K., Magliola, C., Le Huërou-Luron, I. and Louveau, I., 2009. Impact of intrauterine growth retardation and early protein intake on growth, adipose tissue, and the insulin-like growth factor system in piglets. Pediatric Research 65: 45-50. https://doi. org/10.1203/PDR.0b013e318189b0b4.

Musser, R.E., Dritz, S.S., Davis, D.L., Tokach, M.D., Nelssen, J.L., Goodband, R.D. and Owen, K.Q., 2007. Effects of L-carnitine in the gestating sow diet on fetal muscle development and carcass characteristics of the offspring. Journal of Applied Animal Research 31: 105-111. https://doi. org/10.1080/09712119.2007.9706642.

Nissen, P.M., Danielsen, V.O., Jorgensen, P.F. and Oksbjerg, N., 2003. Increased maternal nutrition of sows has no beneficial effects on muscle fiber number or postnatal growth and has no impact on the meat quality of the offspring. Journal of Animal Science 81: 3018-3027. https:// doi.org/10.2527/2003.81123018x.

Oksbjerg, N., Krogh, U., Jensen, J.A., Møller, H.S., Ramaekers, P., Rasmussen, M.K., Therkildsen, M. and Theil, P.K., 2019. Supplementation of sows with L-Arginine during gestating and lactation affects muscle traits of offspring related with postnatal growth and meat quality: From conception to consumption. Meat Science 152: 58-64. https://doi.org/10.1016/j. meatsci.2019.02.004. 
Oster, M., Murani, E., Metges, C.C., Ponsuksili, S. and Wimmers, K., 2012. A gestational high protein diet affects the abundance of muscle transcripts related to cell cycle regulation throughout development in porcine progeny. PLoS ONE 7: e34519. https://doi.org/10.1371/ journal.pone.0034519.

Palencia, J.Y.P., Lemes, M.A.G., Garbossa, C.A.P., Abreu, M.L.T., Pereira, L.J. and Zangeronimo, M.G., 2018. Arginine for gestating sows and foetal development: A systematic review. Journal of Animal Physiology and Animal Nutrition 102: 204-213. https://doi.org/10.1111/jpn.12679.

Paredes, S.P., Jansman, A.J., Verstegen, M.W., Awati, A., Buist, W., den Hartog, L.A., Van Hees, H.M., Quiniou, N., Hendriks, W.H. and Gerrits, W.J., 2012. Analysis of factors to predict piglet body weight at the end of the nursery phase. Journal of Animal Science 90: 3243-3251. https:// doi.org/10.2527/jas.2011-4574.

Pena, R.N., Ros-Freixedes, R., Tor, M. and Estany, J., 2016. Genetic marker discovery in complex traits: a field example on fat content and composition in pigs. International Journal of Molecular Science 17: 2100. https://doi.org/10.3390/ijms17122100.

Perruchot, M.H., Lefaucheur, L., Barreau, C., Casteilla, L. and Louveau, I., 2013. Age-related changes in the features of porcine adult stem cells isolated from adipose tissue and skeletal muscle. American Journal of Physiology 305: C728-C738. https://doi.org/10.1152/ajpcell.00151.2013.

Perruchot, M.H., Lefaucheur, L., Louveau, I., Mobuchon, L., Palin, M.F., Farmer, C. and Gondret, F., 2015. Delayed muscle development in small pig fetuses around birth cannot be rectified by maternal early feed restriction and subsequent overfeeding during gestation. Animal 9: 19962005. https://doi.org/10.1017/S1751731115001202.

Quesnel, H., Père, M.C., Louveau, I., Lefaucheur, L., Perruchot, M.H., Prunier, A., Pastorelli, H., Meunier-Salaün, M.C., Gardan-Salmon, D., Merlot, E. and Gondret, F., 2019. Sow environment during gestation: part II. Influence on piglet physiology and tissue maturity at birth. Animal 13: 1440-1447. https://doi.org/10.1017/S1751731118003087.

Ramanau,A.,Schmidt,R.,Kluge,H.andEder,K.,2006.Bodycomposition, musclefibrecharacteristics and postnatal growth capacity of pigs born from sows supplemented with L-carnitine. Archives of Animal Nutrition 60: 110-118. https://doi.org/10.1080/17450390600562528.

Ramsay, T.G. and Caperna, T.J., 2009. Ontogeny of adipokine expression in neonatal pig adipose tissue. Comparative Biochemistry and Physiology Part B Biochemical and Molecular Biology 152: 72-78. https://doi.org/10.1016/j.cbpb.2008.09.088.

Ramsay, T.G., Stoll, M.J. and Caperna, T.J., 2010. Adipokine gene transcription level in adipose tissue of runt piglets. Comparative and Biochemical Physiology B Biochemistry and Molecular Biology 155: 97-105. https://doi.org/10.1016/j.cbpb.2009.09.006.

Rehfeldt, C. and Kuhn, G., 2006. Consequences of birth weight for postnatal growth performance and carcass quality in pigs as related to myogenesis. Journal of Animal Science 84 Suppl 13: E113-E123. https://doi.org/10.2527/2006.8413_supplE113x.

Rehfeldt, C., Lang, I.S., Görs, S., Hennig, U., Kalbe, C., Stabenow, B., Brüssow, K.P., Pfuhl, R., Bellmann, O., Nürnberg, G., Otten, W. and Metges, C.C., 2011. Limited and excess dietary protein during gestation affects growth and compositional traits in gilts and impairs offspring fetal growth. Journal of Animal Science 89: 329-341. https://doi.org/10.2527/jas.2010-2970.

Rehfeldt, C., Lefaucheur, L., Block, J., Stabenow, B., Pfuhl, R., Otten, W., Metges, C.C. and Kalbe, C., 2012a. Limited and excess protein intake of pregnant gilts differently affects body composition and cellularity of skeletal muscle and subcutaneous adipose tissue of newborn and weanling piglets. European Journal of Nutrition 51: 151-165. https://doi.org/10.1007/s00394-011-02018. 
Rehfeldt, C., Nissen, P.M., Kuhn, G., Vestergaard, M., Ender, K. and Oksbjerg, N., 2004. Effects of maternal nutrition and porcine growth hormone $(\mathrm{pGH})$ treatment during gestation on endocrine and metabolic factors in sows, fetuses and pigs, skeletal muscle development, and postnatal growth. Domestic Animal Endocrinology 27: 267-285. https://oi.org/10.1016/j. domaniend.2004.06.005.

Rehfeldt, C., Stabenow, B., Pfuhl, R., Block, J., Nürnberg, G., Otten, W., Metges, C.C. and Kalbe, C., 2012b. Effects of limited and excess protein intakes of pregnant gilts on carcass quality and cellular properties of skeletal muscle and subcutaneous adipose tissue in fattening pigs. Journal of Animal Science 90: 184-196. https://doi.org/10.2527/jas.2011-4234.

Romero-Moya, D., Santos-Ocaña, C., Castaño, J., Garrabou, G., Rodríguez-Gómez, J.A., RuizBonilla, V., Bueno, C., González-Rodríguez, P., Giorgetti, A., Perdiguero, E., Prieto, C., MorenNuñez, C., Fernández-Ayala, D.J., Victoria Cascajo, M., Velasco, I., Canals, J.M., Montero, R., Yubero, D., Jou, C., López-Barneo, J., Cardellach, F., Muñoz-Cánoves, P., Artuch, R., Navas, P. and Menendez, P., 2017. Genetic rescue of mitochondrial and skeletal muscle impairment in an induced pluripotent stem cells model of Coenzyme Q. Stem Cells 35: 1687-1703. https:// doi.org/10.1002/stem.2634.

Rudar, M., Fiorotto, M.L., and Davis, T.A., 2019. Regulation of muscle growth in early postnatal life in a swine model. Annual Review of Animal Biosciences 7: 309-335. https://doi.org/10.1146/ annurev-animal-020518-115130.

Salas, R.C. and Mingala, C.N., 2017. Genetic factors affecting pork quality: halothane and rendement napole genes. Animal Biotechnology 28: 148-155. https://doi.org/10.1080/1049 5398.2016.1243550.

SanCristobal, M., Rohart, F., Lascor, C., Bouffaud, M., Trouilh, L., Martin, P.G., Lippi, Y., Tribout, T., Faraut, T., Mercat, M.J., Milan, D. and Liaubet, L., 2015. Exploring transcriptomic diversity in muscle revealed that cellular signaling pathways mainly differentiate five Western porcine breeds. BMC Genomics 16: 1055. https://doi.org/10.1186/s12864-015-2259-9.

Sanchez-Gurmaches, J. and Guertin, D.A., 2014. Adipocyte lineages: tracing back the origins of fat. Biochimica et Biophysica Acta 1842: 340-351. https://doi.org/10.1016/j.bbadis.2013.05.027.

Sarr, O., Gondret, F., Jamin, A., Le Huërou-Luron, I. and Louveau, I., 2011. A high-protein neonatal formula induces a temporary reduction of adiposity and changes later adipocyte physiology. American Journal of Physiology Regulatory Integrative and Comparative Physiology 300: R387-R397. https://doi.org/10.1152/ajpregu.00459.2010.

Sarr O., Louveau, I., Kalbe, C., Metges, C.C., Rehfeldt, C. and Gondret, F., 2010. Prenatal exposure to maternal low or high protein diets induces modest changes in the adipose tissue proteome of newborn piglets. Journal of Animal Science 88: 1626-1641. https://doi.org/10.2527/jas.20092542.

Sarr, O., Louveau, I., Le Huërou-Luron, I. and Gondret, F., 2012. Adipose tissue proteomes of intrauterine growth-restricted piglets artificially reared on a high-protein neonatal formula. Journal of Nutritional Biochemistry 23: 1417-1424. https://doi.org/10.1016/j. jnutbio.2011.09.002.

Schutkowski, A., Kluge, H., Trotz, P., Hause, G., König, B., Wensch-Dorendorf, M. and Stangl, G.I., 2018. Impact of a high-protein diet during lactation on milk composition and offspring in a pig model. European Journal of Nutrition Nov 28. https://doi.org/10.1007/s00394-018-1867-y. 
Shi, Z., Song, W., Sun, Y., Wang, L., Shi, B., Shan, A. and Bi, Z., 2018. Dietary supplementation of l-arginine and chromium picolinate in sows during gestation affects the muscle fibre characteristics but not the performance of their progeny. Journal of Science in Food and Agriculture 98: 74-79. https://doi.org/10.1002/jsfa.8439.

Tan, B., Li, X., Yin, Y., Wu, Z., Liu, C., Tekwe, C.D. and Wu, G., 2012. Regulatory roles for L-arginine in reducing white adipose tissue. Frontiers in Biosciences 17: 2237-2246.

Tao, S., Zhou, T., Saelao, P., Wang, Y., Zhu, Y., Li, T., Zhou, H. and Wang, J., 2019. Intrauterine growth restriction alters the genome-wide DNA methylation profiles in small intestine, liver and longissimus dorsi muscle of newborn piglets. Current Protein and Peptide Science 20: 713-726. https://doi.org/10.2174/1389203720666190124165243.

Traustadottir, G.A., Kosmina, R., Sheikh, S.P., Jensen, C.H. and Andersen, D.C., 2013. Preadipocytes proliferate and differentiate under the guidance of Delta-like 1 homolog (DLK1). Adipocyte 2: 272-275. https://doi.org/10.4161/adip.24994.

Van Laere, A.S., Nguyen, M., Braunschweig, M., Nezer, C., Collette, C., Moreau, L., Archibald, A.L., Haley, C.S., Buys, N., Tally, M., Andersson, G., Georges, M. and Andersson, L., 2003. A regulatory mutation in IGF2 causes a major QTL effect on muscle growth in the pig. Nature 425: 832-836. https://doi.org/10.1038/nature02064.

Villa-Vialaneix, N., Liaubet, L., Laurent, T., Cherel, P., Gamot, A. and SanCristobal, M., 2013. The structure of a gene co-expression network reveals biological functions underlying eQTLs. PLoS ONE 8, e60045. https://doi.org/10.1371/journal.pone.0060045.

Voillet, V., SanCristobal, M., Lippi, Y., Martin, P.G, Iannuccelli, N., Lascor, C., Vignoles, F., Billon, Y., Canario, L. and Liaubet, L., 2014. Muscle transcriptomic investigation of late fetal development identifies candidate genes for piglet maturity. BMC Genomics 15: 797. https:// doi.org/10.1186/1471-2164-15-797.

Voillet, V., San Cristobal, M., Père, M.C., Billon, Y., Canario, L., Liaubet, L. and Lefaucheur, L., 2018. Integrated analysis of proteomic and transcriptomic data highlights late fetal muscle maturation process. Molecular and Cellular Proteomics 17: 672-693. https://doi.org/10.1074/ mcp.M116.066357.

Wang, J., Chen, L., Li, D., Yin, Y., Wang, X., Li, P., Dangott, L.J., Hu, W. and Wu, G., 2008. Intrauterine growth restriction affects the proteomes of the small intestine, liver, and skeletal muscle in newborn pigs. Journal of Nutrition 138: 60-66. https://doi.org/10.1093/jn/138.1.60.

Wheatley, S.M., El-Kadi, S.W., Suryawan, A., Boutry, C., Orellana, R.A., Nguyen, H.V., Davis, S.R. and Davis, T.A., 2014. Protein synthesis in skeletal muscle of neonatal pigs is enhanced by administration of $\beta$-hydroxy- $\beta$-methylbutyrate. American Journal of Physiology Endocrinology and Metabolism 306: E91-E99. https://doi.org/10.1152/ajpendo.00500.2013.

Wigmore, P.M. and Stickland, N.C., 1983. Muscle development in large and small pig fetuses. Journal of Anatomy 137: 235-245.

Williams, P.J., Marten, N., Wilson, V., Litten-Brown, J.C., Corson, A.M., Clarke, L., Symonds, M.E. and Mostyn, A., 2009. Influence of birth weight on gene regulators of lipid metabolism and utilization in subcutaneous adipose tissue and skeletal muscle of neonatal pigs. Reproduction 138: 609-617. https://doi.org/10.1530/REP-08-0445.

Wilson, F.A., Suryawan, A., Orellana, R.A., Kimball, S.R., Gazzaneo, M.C., Nguyen, H.V., Fiorotto, M.L. and Davis, T.A., 2009. Feeding rapidly stimulates protein synthesis in skeletal muscle of neonatal pigs by enhancing translation initiation. Journal of Nutrition 139: 1873-1880. https:// doi.org/10.3945/jn.109.106781. 
Wilson, M.E., Biensen, N.J., Youngs, C.R. and Ford, S.P., 1998. Development of Meishan and Yorkshire littermate conceptuses in either a Meishan or Yorkshire uterine environment to day 90 of gestation and to term. Biology of Reproduction 58: 905-910. https://doi.org/10.1095/ biolreprod58.4.905.

Wilson, M.E., Biensen, N.J., Ford, S.P., 1999. Novel insight into the control of litter size in pigs, using placental efficiency as a selection tool. Journal of Animal Science 77: 1654-1658. https:// doi.org/10.2527/1999.7771654x.

Wimmers, K., Fiedler, I., Hardge, T., Murani, E., Schellander, K. and Ponsuksili, S., 2006. QTL for microstructural and biophysical muscle properties and body composition in pigs. BMC Genetics 7: 15. https://doi.org/10.1186/1471-2156-7-15.

Won, S., Jung, J., Park, E. and Kim, H., 2018. Identification of genes related to intramuscular fat content of pigs using genome-wide association study. Asian-Australasian Journal of Animal Science 31: 157-162. https://doi.org/10.5713/ajas.17.0218.

Zhang, L., Wang, Y., Kong, Y., Ahmad, H., Yan, R., Dong, L., Zhang, J. and Wang, T., 2018. Effects of intrauterine growth retardation on growth, meat quality and muscle fiber composition of pigs. Pakistan Journal of Zoology 50: 1137-1146. https://doi.org/10.17582/journal. pjz/2018.50.3.1137.1146.

Zhang, S., Li, X., Li, L. and Yan, X., 2011. Autophagy up-regulation by early weaning in the liver, spleen and skeletal muscle of piglets. British Journal of Nutrition 106: 213-217. https://doi. org/10.1017/S0007114511001000.

Zheng, Q., Lin, J., Huang, J., Zhang, H., Zhang, R., Zhang, X., Cao, C., Hambly, C., Qin, G., Yao, J., Song, R., Jia, Q., Wang, X., Li, Y., Zhang, N., Piao, Z., Ye, R., Speakman, J.R., Wang, H., Zhou, Q., Wang, Y., Jin, W., Zhao, J., 2017. Reconstitution of UCP1 using CRISPR/Cas9 in the white adipose tissue of pigs decreases fat deposition and improves thermogenic capacity. Proceedings of the National Academy of Sciences of the USA 114: E9474-E9482. https://doi. org/10.1073/pnas.1707853114.

Zhou, H., Chen, Y., Lv, G., Zhuo, Y., Lin, Y., Feng, B., Fang, Z., Che, L., Li, J., Xu, S. and Wu, D., 2016. Improving maternal vitamin D status promotes prenatal and postnatal skeletal muscle development of pig offspring. Nutrition 32: 1144-1152. https://doi.org/10.1016/j. nut.2016.03.004. 